\title{
Perlindungan atas Hak Anak yang Terabaiakan (Studi Kasus Yayasan Anak Yatim di Surabaya)
}

\author{
Murni $^{1}$, Djulaeka ${ }^{1,2}$ \\ ${ }^{1}$ Fakultas Hukum Universitas Trunojoyo Madura \\ ${ }^{2}$ Lembaga Penelitian dan Pengabdian Masyarakat Universitas Trunojoyo Madura
}

Email: djulaekadjoerou@gmail.com

Naskah diterima 20 Desember 2019, Revisi 15 Januari 2019, Terbit 20 April 2019

\begin{abstract}
Abstrak
DOI: http://dx.doi.org/10.21107/pmt.v12i1.5179

Pasal 53 ayat 2 UU HAM menyebutkan bahwa "Setiap anak sejak kelahirannya, berhak atas suatu nama dan status kewarganegaraannya". Namun dalam keenyataan menunjukkan bahwa tidak semua anak memiliki akta kelahiran. Salah satu kenyataan terjadi pada Yayasan Anak Yatim di wilayah Surabaya, terdapat dua puluh lima persen anak tidak memiliki akta kelahiran. Dengan lahirnya Undang-undang Nomor 23 Tahun 2006 tentang Administrasi Kependudukan, dan dengan dijaminnya pencatatan perkawinan bagi para penghayat, maka setiap anak yang lahir dari pasangan penghayat dengan sendirinya berhak mendapatkan akta kelahiran. Artikel ini mengulas secara hukum dan persoalan kendala dalam pelaksanaan pendaftaran sesuai dengan target capaian program IbM penulis. Hasil menunjukkan bahwa kecenderungan para orang tua tidak melakukan pendaftaran atau pengurusan akta kelahiran anaknya dikarenakan faktor tempat tinggal dan pendidikan yang minim sehingga terdapat anggapan bahwa akta kelahiran bukan hal penting.
\end{abstract}

Kata kunci : anak yatim, perlindungan hukum, akta kelahiran

\section{PENDAHULUAN}

Hak pertama anak setelah dilahirkan adalah identitas yang meliputi nama, orangtua (silsilah keturunan) dan kewarganegaraan yang dituangkan dalam bentuk akta kelahiran. Hak ini akan menentukan pengakuan, pemenuhan dan perlindungan anak yang lainnya, seperti hak keperdataan (waris, dan nafkah), akses terhadap pendidikan, kesehatan, dan lain-lain. Hak atas akta kelahiran dijamin dalam Undang-undang Nomor 39 Tahun 1999 tentang Hak Asasi Manusia, Undang-undang Nomor 23 Tahun 2002 tentang Perlindungan Anak, Undangundang Nomor 12 Tahun 2006 tentang Kewarganegaraan dan Undang-undang Nomor 23 Tahun 2006 tentang Administrasi Kependudukan.

Akta kelahiran merupakan dokumen hukum yang sangat penting yang menunjukkan identitas seorang anak serta merupakan bentuk pengakuan negara terhadap keberadaan seseorang di depan hukum. Hak identitas bagi seorang anak ditegaskan dalam Pasal 5 Undang-undang Nomor 23 Tahun 2002 tentang Perlindungan Anak, bahwa "Setiap anak berhak atas suatu nama sebagai identitas diri dan status kewarganegaraan". Faktanya, saat ini masih banyak anak Indonesia yang identitasnya tidak tercatat dalam akta kelahiran. Hampir 25\% (dua lima persen) tidak memiliki akta kelahiran. Dinas Kependudukan dan Catatan Sipil (Dispendukcapil) Surabaya mencatat ada 271.443 anak belum memiliki akta kelahiran. (Jawa Pos, 24 2016), artinya ini ada $53,50 \%$ penduduk Surabaya belum memiliki akte kelahiran. Berdasarkan data dari Dispendukcapil Surabaya 2014, komposisi usia anak yang belum memiliki akte kelahiran sebagai berikut:

Tabel 1.Jumlah Anak yang belum Memiliki Akta Kelahiran di Kota Surabaya

\begin{tabular}{|c|c|c|}
\hline NO & $\begin{array}{c}\text { Usia Anak } \\
\text { ( Tahun) }\end{array}$ & $\begin{array}{c}\text { Jumlah } \\
\text { (Orang) }\end{array}$ \\
\hline 1. & $0-1$ & 2.692 \\
\hline 2. & $1-5$ & 34.359 \\
\hline 3. & $5-18$ & 234.392 \\
\hline
\end{tabular}

Pemkot Surabaya melalui Dinas Kependudukan dan Catatan Sipul (Dispendukcapil) berusaha membantu masyarakat Surabaya dalam mengurus akte kelahiran dengan memberikan kemudahan. Peraturan Wali Kota 
(Perwali) Surabaya Nomor 39 Tahun 2013, pada pasal 28A menekankan bahwa "penduduk dibebaskan dari sanksi administratif berupa denda jika yang bersangkutan memiliki surat keterangan miskin dari lurah setempat".

Surat Edaran Mahkamah Agung (MA) Nomor 1 Tahun 2013 telah menghapus kewajiban pemohon mengurus melalui penetapan Pengadilan Negeri. Hal ini berlaku bilamana keterlambatan akta kelahiran melebihi jangka waktu satu tahun dan kini masyarakat yang terlambat mengurus akta kelahiran tak perlu lagi melalui penetapan Pengadilan Negeri. Dengan tidak tercatatnya identitas seorang anak dalam akta kelahiran, maka secara hukum keberadaannya dianggap tidak ada. Kondisi ini tidak hanya karena ketidaktahuan masyarakatakan arti penting akta kelahiran, biaya yang tidak terjangkau dan prosedur yang panjang, namun karena sikap diskriminatif terhadap mereka, yang dipandang sebagai "yang lain" atau berbeda dari kelompok mayoritas.

Menurut peraturan yang berlaku di Indonesia, pencatatan kelahiran secara tidak langsung merupakan turunan dari pencatatan perkawinan. Persoalannya, terdapat perkawinan yang tidak bisa dicatatkan di catatan sipil karena interpretasi undang-undang yang berbeda, seperti kasus yang dialami para Penghayat Kepercayaan Terhadap Tuhan Yang Maha Esa. Mereka tidak bisa memiliki dokumen perkawinan dari negara, karena kepercayaan mereka tidak diakui negara. Akibatnya, anak-anak yang lahir mengalami kesulitan untuk mendapatkan akta kelahiran. Jika bias mendapatkan akta kelahiran maka status anak dianggap bukan berasal dari perkawinan yang sah (anak luar kawin) dan hanya memiliki nama ibu dalam akta. Walhasil, si anak hanya memiliki hubungan hukum dengan ibunya dalam hal hak waris, hak nafkah dan lain-lain.

\section{Akta Kelahiran dalam Perpektif Undang-undang Nomor 23 Tahun 2006 tentang Administrasi Kependudukan}

Dengan lahirnya Undang-undang Nomor 23 Tahun 2006 tentang Administrasi Kependudukan, dan dengan dijaminnya pencatatan perkawinan bagi para penghayat, maka setiap anak yang lahir dari pasangan penghayat dengan sendirinya berhak mendapatkan akta kelahiran. Undang-undang Nomor 23 Tahun 2006 tentang Administrasi Kependudukan, menegaskan setiap kelahiran wajib dilaporkan oleh penduduk kepada instansi pelaksana di tempat terjadinya peristiwa kelahiran paling lambat 60 (enam puluh) hari sejak kelahiran. Sedangkan untuk kelahiran mati dilaporkan paling lambat 30 (tiga puluh) hari sejak lahir mati. Pembatasan jangka waktu pelaporan ini akan menentukan jenis akta kelahiran yang dikeluarkan dan prosedur pembuatannya. Misalkan untuk pencatatan kelahiran yang melampaui batas waktu 1 (satu) tahun dilaksanakan berdasarkan penetapan Pengadilan Negeri.

Akta kelahiran digolongkan menurut jarak waktu pelaporan dengan kelahiran. Tetapi setiap golongan memiliki kekuatan hukum yang sama. Adapun ketiga jenis akta kelahiran tersebut adalah:

(1) Akta Kelahiran Umum, yaitu akta kelahiran yang dibuat berdasarkan laporan kelahiran yang disampaikan dalam batas waktu selambat-lambatnya 60 (enampuluh) hari kerja bagi WNI dan 10 (sepuluh) hari kerja bagi WNA sejak tanggal kelahiran bayi;

(2) Akta Kelahiran Istimewa, yaitu akta kelahiran yang dibuat berdasarkan laporan kelahiran yang telah melampaui batas waktu 60 (enam puluh) hari kerja bagi WNI dan 10 (sepuluh) hari kerja bagi WNA sejak tanggal kelahiran bayi;

(3) Akta Kelahiran Dispensasi, yaitu akta kelahiran yang dibuat berdasarkan Program Pemerintah untuk memberikan kemudahan bagi mereka yang lahir sampai dengan tanggal 31 Desember 1985 dan terlambat pendaftaran/pencatatan kelahirannya.

Penerbitan akta kelahiran dilakukan oleh Dinas Kependudukan dan Catatan Sipil Kabupaten/Kotamadya. Adapun persyaratan untuk membuat akta kelahiran adalah sebagai berikut : 
(1) Surat Keterangan kelahiran dari Rumah Sakit, Dokter, Bidan, Pilot, Nakhoda;

(2) Surat Tanda Bukti Perkawinan Orang Tua;

(3) Surat Keterangan Kelahiran dari Lurah;

(4) Fotocopy Kartu Keluarga/Kartu Tanda Penduduk yang dilegalisir Lurah

\section{Tanggung Jawab Orang Tua, Negara, Pemerintah dan Pemerintah Daerah}

Akte kelahiran adalah bentuk identitas setiap anak yang menjadi bagian tidak terpisahkan dari hak sipil dan politik warga negara. Hak atas identitas merupakan bentuk pengakuan negara terhadap keberadaan seseorang di depan hukum. Akibat banyaknya anak yang tidak memiliki akte kelahiran, banyak anak kehilangan haknya untuk mendapat pendidikan maupun jaminan sosial lainnya. Dalam penanganan perkara Anak yang berhadapan dengan Hukum $(\mathrm{ABH})$, anak juga kerap dirugikan dan kehilangan haknya karena penentuan usia di proses peradilan berdasarkan akte kelahiran.

Hak identitas bagi seorang anak dinyatakan tegas dalam Pasal 5 -undang Nomor 23 Tahun 2002 tentang Perlindungan Anak, menyebutkan bahwa "Setiap anak berhak atas suatu nama sebagai identitas diri dan status kewarganegaraan". Kemudian hal ini juga ditegaskan pada Pasal 27 ayat (1) dan (2) yang menyatakan, ayat (1) "Identitas diri setiap anak harus diberikan sejak kelahirannya", dan ayat (2) menyebutkan bahwa "identitas sebagaimana dimaksud ayat (1) dituangkan dalam akte kelahirann". Sementara itu UUD 1945 Pasal 28 D ayat (1) menyatakan bahwa"setiap orang berhak atas pengakuan, jaminan, perlindungan, dan kepastian hukum yang adil serta perlakuan yang sama di hadapan hukum". Selain itu UUD 1945 juga memberikan jaminan atas status kewarganegaraan sebagaimana diatur dalam $28 \mathrm{D}$ ayat (4) yang menyatakan, "setiap orang berhak atas status kewarganegaraan".

Selama ini pembuatan akte kelahiran diatur dalam UU No. 23 tahun 2006 tentang Administrasi Kependudukan.
Dalam beberapa pasal dalam UU ini ditegaskan bahwa pencatatan kelahiran diwajibkan kepada warga negara melului sistem stelsel aktif penduduk. Penduduk yang harus pro aktif mencatatkan kelahirannya agar bisa memiliki akte kelahiran. Hal ini tercantum dalam Pasal $3,4,27$ ayat 1,29 ayat 1 dan 4,30 ayat 1 dan 6,32 ayat 1 dan 2,90 ayat 1 dan 2 serta penjelasan Umum Undang-undang Nomor 23 tahun 2006 tentang Administrasi Kependudukan. Pasal-pasal tersebut mengatur keharusan setiap warga negara melaporkan kelahirannya sampai sanksi denda bagi siapa yang melanggar.

Pencatatan kelahiran merupakan hal yang sangat penting bagi orang yang bersangkutan maupun bagi negara, karena dengan adanya pencatatan kelahiran yang teratur maka berbagai persoalan dapat diselesaikan, misalnya dapat diketahui pertambahan penduduk, hal ini akan membantu pemerintah dalam menetapkan kebijaksanaan yang berhubungan dengan masalah kependudukan. Ada 3 (tiga) alasan mengapa pencatatan kelahiran itu penting, yaitu :

1. Pencatatan kelahiran adalah pengakuan formal mengenai keberadaan seorang anak, secara individual terhadap negara dan status anak dalam hukum;

2. Pencatatan kelahiran adalah elemen penting dari perencanaan nasional. Untuk anak-anak, memberikan dasar demografis agar strategis yang efektif dapat dibentuk;

3. Pencatatan kelahiran adalah cara untuk mengamankan hak anak lain, misalnya identifikasi anak sesudah berperang, anak ditelantarkan atau diculik, agar anak dapat mengetahui orang tuanya (khususnya jika lahir diluar nikah), sehingga mereka mendapat akses pada sarana atau prasarana dalam perlindungan negara dalam batas usia hukum (misalnya : pekerjaan, rekruitment $A B R I$, dalam sistem peradilan anak) serta mengurangi atau kemungkinan penjualan bayi.

Selain undang-undang ini memberikan kewajiban dan tanggung jawab kepada 
negara, pemerintah, pemerintah daerah dan masyarakat, undang-undang ini juga memberikan kewajiban dan tanggung jawab kepada orang tua dalam hal perlindungan kepada anak, mengasuh, memelihara, mendidik, dan melindungi anak, menumbuhkembangkan anak sesuai dengan kemampuan, bakat, dan minatnya, mencegah terjadinya perkawinan pada usia anak dan memberikan pendidikan karakter dan penanaman nilai budi pekerti pada anak.

Untuk anak-anak yang tidak diketahui orangtua danasal-usulnya seperti anakanak yang dibuang, maka pencatatan kelahirannya didasarkan pada laporan orang yang menemukan dilengkapi Berita Acara Pemeriksaan (BAP) dari kepolisian. Anak adalah bagian yang tidak terpisahkan dari keberlangsungan hidup manusia dan keberlangsungan sebuah bangsa dan negara. Agar kelak mampu bertanggung jawab dalam keberlangsungan bangsa dan negara, setiap anak perlu mendapat perlindungan dan kesempatan yang seluas-luasnya untuk tumbuh dan berkembang secara optimal baik fisik, mental, maupun sosial. Untuk itu, perlu dilakukan upaya perlindungan untuk mewujudkan kesejahteraan anak dengan memberikan jaminan terhadap pemenuhan hak-haknya tanpa adanya perlakuan diskriminatif.

Mengenai tanggung jawab negara, pemerintah dan pemerintah daerah dalam Undang-Undang Nomor 35 Tahun 2014 tentang Perubahan Atas Undang-Undang Nomor 23 Tahun 2002 Tentang Perlindungan Anak, diatur dalam beberapa pasal yang diantaranya mewajibkan dan memberikan tanggung jawab untuk menghormati pemenuhan hak anak tanpa membedakan suku, agama, ras, golongan, jenis kelamin, etnik, budaya dan bahasa, status hukum, urutan kelahiran, dan kondisi fisik dan/atau mental, serta melindungi, dan menghormati hak anak dan bertanggung jawab dalam merumuskan dan melaksanakan kebijakan di bidang penyelenggaraan perlindungan anak. Kemudian dalam undang-undang ini pemerintah daerah berkewajiban dan bertanggung jawab untuk melaksanakan dan mendukung kebijakan nasional dalam penyelenggaraan perlindungan anak di daerah yang dapat diwujudkan melalui upaya daerah membangun kabupaten/kota layak anak, serta memberikan dukungan sarana, prasarana, dan ketersediaan sumber daya manusia dalam penyelenggaraan perlindungan anak.

Selain kewajiban dan tanggung jawab sebagaimana di atas negara, pemerintah, dan pemerintah daerah juga menjamin perlindungan, pemeliharaan, dan kesejahteraan anak dengan memperhatikan hak dan kewajiban orang tua, wali, atau orang lain yang secara hukum bertanggung jawab terhadap anak, mengawasi penyelenggaraan perlindungan anak, menjamin anak untuk mempergunakan haknya dalam menyampaikan pendapat sesuai dengan usia dan tingkat kecerdasan anak, serta kewajiban dan tanggung jawab yang paling penting adalah menyelenggarakan pendidikan dasar minimal 9 (sembilan) tahun untuk semua anak dan memberikan kesempatan yang seluas-luasnya kepada anak untuk memperoleh pendidikan serta memberikan biaya pendidikan atau bantuan cuma-cuma atau pelayanan khusus bagi anak dari kurang mampu, anak terlantar, dan anak yang tinggal didaerah terpencil. Semoga amanah besar yang diberikan oleh undang-undang ini dapat dilaksanakan oleh negara, pemerintah dan pemerintah daerah demi mewujudkan tanggung jawab dan kewajibannya terhadap anak yang merupakan generasi bangsa.

\section{Faktor Yang Menjadi Kendala Dalam Pendaftaran Akta Kelahiran}

Selain tanggung jawab negara, pemerintah dan pemerintah daerah, undang-undang ini pun memberikan amanah, tanggung jawab dan kewajiban kepada masyarakat, sehingga masyarakat tidak boleh lagi berpangku tangan dan bermasa bodoh dalam hal perlindungan kepada anak, diantara kewajiban dan tanggung jawab masyarakat diantaranya adalah melakukan kegiatan peran serta masyarakat dalam penyelenggaraan perlindungan anak. Permasalahan yang dihadapi pihak Yayasan adalah: 
1. Panti asuhan kurang memahami hakhak anak terkait dengan pendokumentasian identitas anak pada akte kelahiran.

2. Panti asuhan kurang memahami persyaratan administratif pengurusan akte kelahiran.

3. Panti asuhan kurang memahami prosedur pengurusan Akte kelahiran.

4. Pengalaman Panti asuhan dalam mengurus akte kelahiran memakan waktu penerbitan cukup lama, sementara anak dihadapkan pada kebutuhan akan pendidikan melanjutkan sekolah ke jenjang yang lebih tinggi dimana memerlukan syarat adanya akta kelahiran.

5. Panti Asuhan beranggapan mengurus akte kelahiran memerlukann biaya cukup besar apalagi jika anak sudah besar.

Yayasan Darul Aitam dan Darul Khidmat Sidogiri yang terletak di Surabaya sebagai mitra lbM merupakan yayasan yang mengurusi anak yatim piatu dengan kondisi yang cukup memprihatinkan. Data awal teridentifikasi sejumlah 18 (delapan belas) anak yatim piatu yang tidak memiliki akte kelahiran, namun kondisi riil anak yatim yang tidak memiliki akta kelahiran terhitung sebanyak 10 (sepuluh) anak. Dalam perkembangan terungkap bahwa permasalahn yang dihadapi oleh kedua mitra banyak disebabkan oleh persoalan banyaknya dokumen penunjang prasyarat yang tidak dimiliki oleh orangtua anak / ibu yang ada di kedua mitra, padahal keberadaan orang tua/ orang tua bagi anak yatim merupakan bagian penting dalam pemenuhan kelengkapan administrasi yang dibutuhkan dalam pendafaran perolehan akta kelahiran.

Rata-rata para Orang tua yang menitipkan puta/putrinya di yayasan mitra IbM berpendidikan SD sampai SMP serta tidak memiliki penghasilan yang tetap dan bekerja secara serabutan. Ketidaktahuan akan pentingnya akta kelahiran serta pengaruh pada masa depan anak inilah yang menyebabkan Orang tua atau bahkan ada Orang tua yang menikah lagi tidak mempedulikan kepentingan si anak. Sebenarnya peran Yayasan dapat dianggap penting dalam persoalan kepemilikan akta kelahiran anak yang menjadi tanggungjawabnya apabila pada saat anak dititipkan pada Yayasan tetap diwajibkan memenuhi syarat bahwa anak yang bersangkutan harus jelas status hukumnya, misalnya bukan semata-mata kelengkapan Kartu Keluarga saja namun dapat dipersyaratkan lebih dari itu, salah satunya akta kelahiran atau surat keterangan lahir dari bidan, rumah sakit ataupun dukun bayi yang membantu proses kelahiran anak.

Saat sosialisasi ataupun penyuluhan yang dilakukan oleh pihak Dispendukcapil dan Lembaga Perlindungan Anak Surabaya, para Orang tua anak yatim menyadari pentingnya akta kelahiran bagi anak dan sangat berterima kasih karena selama ini kebanyakan mereka melakukan pembiaran terhadap hak anak yang semestinya diperoleh. Proses jemput bola dalam pengumpulan berkas sebenarnya cukup direspon dengan baik, namun keterbatasan mereka dalam penyimpanan dokumen menyebabkan tertundanya pemberkasan. Meski demikian keberhasilan pelaksanaan pendaftaran dan terpenuhinya hak anak telah ditunjukkan dengan terdapatnya 4(empat) akta yang sudah berhasil diperoleh dan 2 (dua) dokumen dalam proses serta 4 (empat) lainnya dalam proses pemenuhan pelaporan pada kepolisian atas hilangnya beberapa dokumen orangtua, salah satunya akta perkawinan.

\section{KESIMPULAN}

1. Rata-rata para Orang tua anak yatim kurang memiliki kepedulian dalam mengurus akta kelahiran bagi anaknya;

2. Faktor pendidikan dan ketidaktahuan proses pengurusan akta kelahiran menyebabkan adanya pembiaran tidak mengurus kepentingan anak untuk memiliki akta kelahiran;

3. Kurang berperan secara maksimal pihak yayasan dalam pemenuhan persyaratan masuk sebagai anak panti asuhan;

4. Kedua mitra telah teridentifikasi ada 10 (sepuluh) anak yang masih belum memiliki akta kelahiran.

\section{SARAN}

1. Peran pemerintah daerah diharapkan secara berkelanjutan melakukan 
penyuluhan terkait pentingnya akta kelahiran bagi anak, khususnya untuk yayasan anak panti asuhan;

2. Perlu pendampingan secara berkelanjutan dari pihak kelurahan ataupun pihak ketiga yang dapat membantu proses pengurusan dan pendaftaran akta kelahiran;

3. Peran aktif Orang tua anak yatim harus secara berkesinambungan mengetahui hak-hak anak yang semestinya diperoleh.

\section{DAFTAR PUSTAKA}

Undang-undang Nomor 23 Tahun 2006 tentang Administrasi Kependudukan.

Undang-Undang Nomor 35 Tahun 2014 tentang Perubahan Atas UndangUndang Nomor 23 Tahun 2002 Tentang Perlindungan Anak.

Peraturan Wali Kota (Perwali) Surabaya Nomor 39 Tahun 2013.

Surat Edaran Mahkamah Agung (MA) Nomor 1 Tahun 2013. 